\title{
Different estimations of heritabilities in dependence of major gene effects (Brief Report)
}

\author{
Unterschiedliche Schätzung von Heritabilitäten in \\ Abhängigkeit von Hauptgeneffekten (Brief Report)
}

\section{BERND BUSKE and NICOLAS GENGLER}

Gembloux Agricultural University, Gembloux, Belgium

\section{Background}

Knowledge of major gene effects for quantitative traits (e.g. milk performance traits) and the consequent selection of animals with desirable genotypes can accelerate breeding progress and can therefore equal large gain in profits. It is generally accepted that in most cases, the total breeding value for quantitative traits of any animal can be divided in one or some major gene effects and a pure random polygenic component, in which the latter results from a finite number of remaining loci (FERNANDO et al. 1994). Thus, the aim of this study was to investigate, how the estimation of heritability is influenced by the application of two different models, one of them containing a major single gene effect. The myostatin gene (MSTN) was chosen because the knowledge of this gene effect is used for selection decisions in the Dual Purpose Belgian Blue Breed (DP-BBB) in the Walloon Region of Belgium.

\section{Procedures}

A field dataset including 1,455 genotyped DP-BBB cows with 40,269 test-day (TD) records was available. All cows were genotyped for the $11 \mathrm{bp}$-deletion in the coding sequence of MSTN using a method adapted from FAHRENKRUG et al. (1999). Genotype and allele frequencies were $0.181(+/+), 0.371(\mathrm{mh} /+)$ and $0.447(\mathrm{mh} / \mathrm{mh})$ as well as $0.37(+)$ and 0.63 $(\mathrm{mh})$, respectively.

TD records per lactation were sampled between 1991 and 2008. For all traits, the following linear single trait mixed inheritance test-day model was used

$$
y=\mu+X \beta+H h+W i+Z p+Z u+Z Q g+e
$$

whereas $y$ is a vector of TD records representing the phenotype of the animal, $\mu$ is the overall mean, $\beta$ represents a vector of fixed effects, $h$ is a vector for a random herd $\times$ test-day effect, $\boldsymbol{i}$ for a random intra lactation effect, $\boldsymbol{p}$ for a random permanent environment effect, and $\boldsymbol{e}$ represents the residual. The vector $\boldsymbol{u}$ stands for the random polygenic animal effect, and $\boldsymbol{g}$ represents the myostatin genotype effect. Genotype effect was considered as fix including an additive and a dominance effect. The incidence matrices $X, H, W$ and $Z$ link the records to the fixed effects, herd $\times$ test-day, animal $\times$ lactation number and animals, respectively, whereas $Q$ is a matrix linking animals to their myostatin genotype. The second model was the same model as described above, except that the component for the major gene effect 
ZQg was removed. The following five traits were considered: milk, fat and protein yield (kg) and fat and protein content (\%). Apart from the genotype effect, further fixed effects were herd (72 levels), the combination between lactation class (3 levels) and lactation stage (25 levels), the season in month (11 levels), the year of sampling (10 levels) and the age of cows in years at the test-day (7 levels). Concerning lactation class, third and later lactation numbers were combined. For the season, July and August were also combined due to low number of TD records in August. Age of cows at the test-day was assessed for every year, however, cows older than six years were combined to one class, whereas cows up to 2.5 years and cows between 2.5 and 3 years were also addressed to an extra class. The pedigree consisted of 3,511 animals including genotyped cows and their non genotyped relatives and was extracted from the complete pedigree comprising over 956,000 animals, which is permanently updated and used for the official Walloon genetic evaluations (CROQUET et al. 2006). Variance components for all random effects were estimated using always the EM REML procedure (MISZTAL et al. 2002). Starting values for each random effect were obtained by dividing the phenotypical variance of each trait by the number of random effects. Thus, starting values were generally higher as the estimated ones, which is strongly recommended by MISZTAL (2008) and TSURUTA et al. (2004).

\section{Results}

Results showed that heritabilities were higher for all traits when the major gene effect was removed from the model except for protein content (Table 1). This was expected because it is well known that the presence of the »+« allele of MSTN leads to increases for milk, fat and protein yield to a considerable amount but not for protein content. Therefore, the variability of the major gene effect was transferred into the random polygenic additive genetic variance. This should be the case when it is assumed that the myostatin gene is responsible for variability for these traits. Furthermore, convergence between permanent environment and random polygenic animal effect was less stable for fat content, when the myostatin gene effect was not included in the model indicating that fixed or systematic effects should be modelled adequately as it is also mentioned by MISZTAL (2008). The results clearly show that estimation of heritability depends strongly on the knowledge and inclusion of major gene effects and therefore, such gene effects should be considered when heritability should be estimated reliably.

Table 1

Estimations of variance components and heritabilities $\left(\mathrm{h}^{2}\right)$ for milk performance traits with or without MSTN gene effect in the model

Schätzung von Varianzkomponenten und Heritabilitäten $\left(h^{2}\right)$ für Milchleistungsmerkmale mit bzw. ohne MSTN Geneffekt im Model

\begin{tabular}{|c|c|c|c|c|c|c|c|c|c|c|}
\hline \multirow{2}{*}{$\begin{array}{l}\text { Trait } \\
\text { Model }\end{array}$} & \multicolumn{2}{|c|}{ Milk yield } & \multicolumn{2}{|c|}{ Protein yield } & \multicolumn{2}{|c|}{ Protein content } & \multicolumn{2}{|c|}{ Fat yield } & \multicolumn{2}{|c|}{ Fat content } \\
\hline & $\begin{array}{l}\text { without } \\
\text { mstn }\end{array}$ & $\begin{array}{l}\text { with } \\
\text { mstn }\end{array}$ & $\begin{array}{l}\text { without } \\
\text { mstn }\end{array}$ & $\begin{array}{l}\text { with } \\
\text { mstn }\end{array}$ & $\begin{array}{l}\text { without } \\
\text { mstn }\end{array}$ & $\begin{array}{l}\text { with } \\
\text { mstn }\end{array}$ & $\begin{array}{l}\text { without } \\
\text { mstn }\end{array}$ & $\begin{array}{l}\text { with } \\
\text { mstn }\end{array}$ & $\begin{array}{c}\text { without } \\
\text { mstn }\end{array}$ & $\begin{array}{l}\text { with } \\
\text { mstn }\end{array}$ \\
\hline$\sigma_{g}^{2}$ & 2.905 & 2.346 & 0.261 & 0.194 & 2.129 & 2.137 & 0.545 & 0.416 & 6.747 & 6.505 \\
\hline$\sigma_{t}^{2^{9}}$ & 13.679 & 13.080 & 1.401 & 1.339 & 8.193 & 8.197 & 2.375 & 2.255 & 31.451 & 31.314 \\
\hline$h^{2}$ & 0.212 & 0.179 & 0.186 & 0.145 & 0.260 & 0.261 & 0.229 & 0.185 & 0.215 & 0.208 \\
\hline
\end{tabular}

$\sigma_{g}^{2}$ additive genetic variance, $\sigma_{t}^{2}$ total variance, All variances except for milk yield were multiplied by 100 


\section{References}

Croquet C, Mayerers P, Gillon A, Vanderick S, Gengler N (2006) Inbreeding depression for global and partial economic indexes, production, type, and functional traits. J Dairy Sci 89, 2257-67

Fahrenkrug SC, Casas E, Keele JW, Smith TP (1999) Technical Note: direct genotyping of the double-muscling locus (mh) in Piedmontese and Belgian Blue cattle by fluorescent PCR. J Anim Sci 77, 2028-30

Fernando RL, Stricker C, Elston RC (1994) The finite polygenic mixed model: an alternative formulation for the mixed model of inheritance. Theor Appl Genet 88, 573-80

Misztal I (2008) Reliable computing in estimation of variance components. J Anim Breed Genet 125, 363-70

Misztal I, Tsuruta S, Strabel T, Auvray B, Druet T, Lee DH (2002) BLUPF90 and related programs (BGF90). Proc. 7th World Congr Genet Appl Livest Prod, Montpellier, France. CD-ROM Commun 28, 07

Tsuruta S, MisztalL I, Lawlor TJ, Klei L (2004) Modeling final scores in US Holsteins as a function of year of classification using a random regression model. Livest Prod Sci 91, 199-207

Received 20 July 2009, accepted 4 October 2010.

Corresponding author:

BERND BUSKE

email: buske.b@fsagx.ac.be

Gembloux Agricultural University, Passage des Déportés, 2, 5030 Gembloux, Belgium 